MPC MAJOR RESEARCH PAPER

\title{
A RHETORICAL DISCOURSE ANALYSIS OF THE STUDENT FACEBOOK GROUP UWO STUDENTS AGAINST ISRAEL APARTHEID WEEK
}

\section{JESSICA RINGEL}

\author{
Dr. Carolyn Meyer
}

The Major Research Paper is submitted

in partial fulfillment of the requirements for the degree of

Master of Professional Communication

Ryerson University

Toronto, Ontario, Canada

25 August 2011 


\section{AUTHOR'S DECLARATION}

I hereby declare that I am the sole author of this Major Research Paper (MRP).

I authorize Ryerson University to lend this MRP to other institutions or individuals for the purpose of scholarly research.

Signature

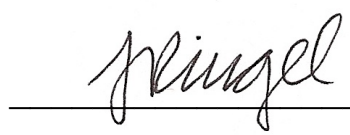

I further authorize Ryerson University to reproduce this MRP by photocopying or by other means, in total or in part, at the request of other institutions or individuals for the purpose of scholarly research.

signature jlimgel 


\begin{abstract}
This MRP will examine the use of rhetorical strategies in an online political discussion group. The Rhetoric of Social Intervention (RSI) model will be used to perform a rhetorical and textual discourse analysis of the comments that users post in the Facebook group UWO Students Against Israel Apartheid Week. Each element of the RSI model (attention, power, need) helps group members to communicate their message through a persuasive approach, possibly leading to the enactment of some type of online or offline political change. Israel Apartheid Week (IAW) is a valuable case study because this annual event occurs in an attempt to instill the ideology that global society should view Israel as an apartheid state. Since ideology and rhetoric form the underpinnings of the RSI model, this lens is relevant to evaluating the use of rhetorical strategies within this particular group. The rhetorical dimensions of online discourse must be further explored in order to provide a more comprehensive understanding of the role of online political communication within a digital era.
\end{abstract}




\section{ACKNOWLEDGMENTS}

It is a pleasure to thank those who made this MRP possible. I would like to express my gratitude to Dr. Carolyn Meyer for being a wonderful supervisor. Her encouragement, support, and invaluable suggestions were able to make this work successful.

I would like to thank Dr. Wendy Freeman for acting as my Second Reader for this project. Her careful attention to refining the contents of this MRP did not go unnoticed.

I also wish to acknowledge my fellow Master's of Professional Communication peers for being great friends, as well as my parents, grandparents, uncle, and sister for their love and ongoing support.

I dedicate this MRP to a true fighter, Bailey, my loving Aunt. 


\section{TABLE OF CONTENTS}

Author's Declaration $\ldots \ldots \ldots \ldots \ldots \ldots \ldots \ldots \ldots \ldots \ldots \ldots$ ii

Abstract ................................

Acknowledgments ......................... iv

1. Introduction $\ldots \ldots \ldots \ldots \ldots \ldots \ldots \ldots \ldots \ldots \ldots \ldots \ldots \ldots \ldots$

2. Literature Review $\ldots \ldots \ldots \ldots \ldots \ldots \ldots \ldots \ldots \ldots \ldots \ldots$

3. Method $\ldots \ldots \ldots \ldots \ldots \ldots \ldots \ldots \ldots \ldots \ldots \ldots \ldots \ldots \ldots \ldots$

4. Results and Discussion $\ldots \ldots \ldots \ldots \ldots \ldots \ldots \ldots \ldots \ldots \ldots \ldots \ldots$

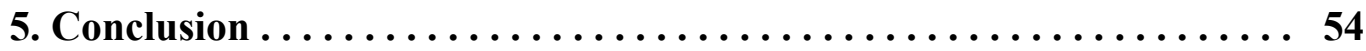

Works Cited ................................. 59

List of Figures

Figure 1. The RSI Model's Components . . . . . . . . . . . . . . . 25

List of Tables

Table 1. The Total Number of RSI Strategies Implemented During IAW . . . 50 


\section{INTRODUCTION}

In recent years, researchers have taken significant interest in evaluating the role of online political communication. In a traditional political realm, an offline community is initially formed. However, today, the ubiquity of the Internet has enabled this type of community to establish a niche within a virtual environment in order to maintain and ground the offline perspective. Virtual environments often encompass the form of an online community: "a social aggregation that emerges from the Internet when enough people carry on public discussions for long enough, with sufficient human feeling, to form webs of personal relationships in cyberspace" (Rheingold 49). These communities provide online users with the opportunity to engage in a variety of discussions and decision-making processes specifically pertaining to current social and political matters. These groups enable users to become politically and socially informed and involved without leaving the comfort of their own homes. For instance, in 1992, the annual Run for the Cure event took place for the first time in Toronto, Canada (Canadian Breast Cancer Foundation). In 1992, participation was largely based on physically running in the event. However, today's online media encourage other forms of participation. Facebook enables runners to join online support groups and pages, convey their personal stories online, and link fundraising tabs to their personal user profiles (Canadian Breast Cancer Foundation). The Canada Birthday Poll in 2007 also exemplifies the creation of an online community for political purposes. On July 1, 2007, Canada's $140^{\text {th }}$ birthday, the CBC News network partnered with Facebook to ask young Canadians what their birthday wish would be for Canada's $140^{\text {th }}$ birthday. Although the wishes were not expected to be of a political nature, the number one wish amongst Canadians was to abolish abortion in Canada (9,736 votes), followed by the wish that Canada would remain pro-choice (8,276 votes) (My Canada). The results of this wish list 
reopened the abortion debate within Canada and Facebook users morphed the medium into a platform for active political discussion. In this way, use of the Internet for political communication contributes significantly to individual political knowledge and awareness. Online political communication has been referred to as the "greatest dialogue move" (Lariscy and Sweetser 176). Since its potentials are being actualized, researchers are encouraged to continue to analyze the intersection of politics and online communities. As studies note, these types of communities have a large impact on the political system:

Political online communities can be structured and organized in very different manners. What they have in common is that they are influencing or willing to influence the functions of the political system, and that is the process of legislation and the definition of norms for society as a whole. The articulation and aggregation of interests, political support, but also political socialization and recruiting of political personnel are usually regarded as central input functions of the political system. (In der Smitten 34)

According to this viewpoint, online political communication can incite reforms for the functionality of the political system. Furthermore, digital media's ability to aggregate information and connect individuals to one another redefines traditional modes of political communication. Social media and networking websites such as Facebook allow for the formation of groups where users can engage in online, peer-to-peer political discussions. These online political communities typically feature conversational forums where individuals post comments, questions, opinions, and more. In general, individuals feel a strong attachment to their political opinions. Since political debates often feature individual attempts to reconcile dissenting political perspectives with the majority opinion, in order to construct, maintain, or subvert certain political perspectives and ideologies in online groups, users implement different kinds of rhetoric within their commentary. This observation illuminates several areas of exploration: what are the implications of using rhetoric in an online community? How can rhetoric be implemented in an 
online environment? What type of rhetoric is implemented specifically in online political discussion groups?

A well-known, controversial political issue that is communicated to the public via online media is Israel Apartheid Week (IAW): an annual event that occurs at academic institutions in an attempt to instill the belief that Israel should be viewed and critiqued as an apartheid state. Each year, an email blast is issued to inform all Canadian university communities about the occurrence of the event week. For IAW 2011, an email with the subject line "IAW on Toronto Campuses" filled the inboxes of students living in the Greater Toronto Area in Canada. The email characterizes IAW as an event that is "a yearly anti-Israel ritual that is intimidating to Jewish students who are often viewed by IAW supporters as proponents of crimes against humanity simply for supporting Israel" (UJA Federation: Public Affairs). In addition to the event week itself, the online, political Facebook group University of Western Ontario (UWO) Students Against Israel Apartheid Week has also garnered notable media attention. In 2010, an article published in the Canadian Jewish News, Canada's largest weekly Jewish newspaper, discusses how the group offers valuable "information about anti-IAW initiatives and suggestions about how to deal with any IAW concerns" (Poliakov 28). Articles covering the creation and contents of the UWO group were also featured in municipal and university publications such as the London Free Press, Ubyssey, and The Gazette. Similarly aligned IAW Facebook groups such as Students Against Israel Apartheid - Carleton, the group for students at Carleton University in Ottawa, Canada, have also received coverage in non-profit, online magazines such as The Canadian Charger (Amdur). IAW Facebook groups of this nature serve as practical case studies for investigating how political ideology, enabled through rhetoric, intersects with the pursuit of action in an online community. 
This research study will investigate the use of rhetorical strategies within the UWO Facebook group. The Rhetoric of Social Intervention (RSI) model will be used to perform a textual and rhetorical discourse analysis of the comments that users posted in the group during IAW 2010. There are three types of rhetorical strategies in the RSI model: attention intervention, power intervention, and need intervention. Each strategy helps group members to communicate their message through a persuasive approach, possibly leading to the enactment of some type of online or offline political change. This study will provide new insight into the rhetorical dimensions of online political discourse because few studies have used the RSI model to analyze a political issue that is conveyed through online media. This study will illustrate communication research (the use of rhetorical strategies) for a new medium (social media websites such as Facebook), which has the potential to contribute to the field of professional communication. A discussion of the underpinnings of IAW will provide the framework for the study to follow.

\section{Israel Apartheid Week (IAW)}

IAW is "an annual international series of events held in cities and campuses across the globe" (IAW). IAW occurs predominantly in cities in Canada, the United States, United Kingdom, and South Africa. The mandate of IAW is to inform various publics about Israel as an apartheid system and to advocate the idea that Jewish-Israeli citizens are given preferential treatment in Israel. The week's primary goal is to:

Contribute to the chorus of international opposition to Israeli apartheid and to bolster support for the demands outlined in the July 2005 Statement issued by over 170 Palestinian civil society organizations: full equality for Arab-Palestinian citizens of Israel, an end to the occupation and colonization of all Arab lands - including the Golan Heights, the Occupied West Bank with East Jerusalem and the Gaza Strip - and dismantling the Wall, and the protection of Palestinian refugees' right to return to their homes and properties. (IAW) 
The cultural tension between Arabs and Israelis, which is played out during IAW, arises from competing claims over the land ownership of Palestine and the Zionist occupation of Palestinian land. While Arabs were already settled in Palestine, in the late 1800s and early 1900s, Theodore Herzl, the father of political Zionism (a Jewish nationalist movement), and Arthur James Balfour, a British foreign secretary, organized Zionist movements to counter antiSemitism and advocate for the creation of a Jewish homeland in Palestine (Tessler 164). Palestinians began to fear that Zionism would threaten their political aspirations, abilities, and goals (Tessler 129). In 1967, these growing tensions resulted in the Six Day War between the Israeli and Arab militaries. During the war, Israel seized the West Bank and the Gaza Strip, which are considered to be the most valuable land spaces in the Middle East (Tessler 397). Today, they are collectively referred to as the Occupied Territories. After the Six Day War, there were intifadas against the Israeli occupation, suicide attacks, and attempts to withdraw militia from the Gaza Strip and the West Bank settlements. Further tensions mounted between the Arabs and Jews living in the mainland and the Occupied Territories. Many Palestinian cities were raided and Palestinians and Israelis living in Gaza were forced to leave their homes. These series of events caused a global reaction; the tension between Arabs and Jews in Israel created tension between Arabs and Jews living in other countries such as Canada. In 2000, a Palestinian community centre was vandalized in Mississauga, Canada (Boldt). In 2004, the library of a Jewish elementary school in Montreal, Canada was firebombed on the first night of Hanukkah (Lurie). In 2008, a swastika was spray-painted on the inside of a bathroom stall at UWO university in London, Canada (Haggarty). Nahla Abdo, a professor of Israeli-Palestinian relations at Carleton University, is quoted in a Carleton Journalism publication: 
What has happened in the Middle East has turned into a religious attack rather than just a straightforward territorial problem. I don't think that Canada, the United States or any country, is totally separated or isolated from another country, particularly when it comes to the Middle East and to Israel. A spillover into Canada is inevitable, considering the ties both communities have with Israel. (Boldt)

Abdo's viewpoint illustrates that "stones thrown in Israel may shatter windows in Canada" (Boldt). The strength of the political ties to Israel that Arabs and Jews across the globe possess sparked the creation of IAW. IAW was constructed so that Arab and Jewish students can voice their political perspectives on university campuses and evaluate Arab-Jewish relations and Israel's cultural practices. Therefore, the political situation in Israel has a significant impact on the manner in which political perspectives are expressed in other areas of the world.

The 2011 academic year marked IAW's seventh consecutive year (Dahan 13). Each year, a full programme for the event week is developed. These programmes encompass various forms such as lectures, films, cultural performances, and demonstrations. At IAW 2010, many campuses featured screenings for the movie Occupation 101, a documentary film that discusses the root causes of the Israeli-Palestinian conflict. IAW often includes the use of flash mobs and on-campus protests where students create spray-painted signs and wave national flags. Many world-renowned political leaders and academics such as Judith Butler, a theorist and professor of ethics and rhetoric at the University of California, Berkeley, have recently become involved in the apartheid discussion. At IAW 2011, Butler spoke at the University of Toronto about her political right to possess an anti-Israel attitude while being of the Jewish faith herself (Balsam). Ishmael Khaldi, a Muslim Bedouin who served in the Israeli Foreign Service, lectured at the University of Edinburgh in an attempt to counter apartheid accusations against Israel by drawing upon his personal experiences to prove that minorities such as himself are granted full rights in Israel. 
Although the mandate of IAW is to educate and promote certain political ideologies regarding Israel, this event week creates an on-campus environment where Jewish students are left feeling threatened and "uncomfortable as their homeland is brazenly attacked without foundation" (Hart 17). The protests are rarely peaceful and the rhetoric used to express certain political perspectives reflects highly polemical debates. Although an increasing number of academic institutions are adopting and approving the conduct of IAW each year, the event week distorts the discourse to prevent a discussion of the most pressing issues. The rigid standpoint that many individuals possess when discussing the Israeli-Palestinian conflict during IAW impedes the ability for students to practice good faith and educated activism, whether online or offline. 


\section{LITERATURE REVIEW}

Drawing from research that employs the RSI model to analyze various social and cultural issues illustrates that there is a link between the use of rhetorical strategies and the formation or reinforcement of political and cultural ideologies. The following studies of online political communication examine how social media and networking sites are used to convey political topics and issues, note the prevalence of using rhetoric in discussions of the Israeli-Palestinian conflict, and classify constructing credibility as one of the most prominent rhetorical strategies.

Existing research emphasizes the importance of language in a political environment:

Language is, in focus, perhaps the most important instrument for success. Communication - the symbolic exchange of meaning - is necessary to all political activity since politics is in some sense "doing by saying." Rhetoric, conveyed through words, contains the very essence of politics. (Hakansson 82)

Thus, an analysis of political communication should focus on the construction of arguments since "politics involve the contest of ideas, beliefs, and meanings to determine the nature of political action" (Finlayson 545).

Previous research also promotes the valuable aspects of political communication when executed in online environments such as social networking sites. However:

Because the Internet has evolved so rapidly, there has been little attention paid to the way in which youth are using social networking sites to engage in politics. Such sites allow individual users to post information and interact with others either one-on-one or in groups. (Baumgartner and Morris 24).

Since most young adults possess user accounts on the Internet, online media can be used to foster political engagement amongst potentially disengaged individuals (Baumgartner and 
Morris 29). In a study, Laura Donnelly-Smith interviewed a student member of a political Facebook group and discovered the value of adding a political dimension to online media. According to the student, social networking websites like Facebook are useful for encouraging student political engagement because:

"We [students] already spend so much time on the phone, texting, and on things like Facebook, and now they are becoming more mainstream - the New York Times is on MySpace now. It's much easier to learn about politics through sites we're already using. People who wouldn't normally educate themselves during an election year now do - it's easier, and more available in formats we are used to" (Donnelly-Smith 38).

According to Donnelly-Smith's study, students feel that social networking sites encourage their interest in becoming politically active and informed. Susanne In der Smitten's research also focuses on the ability for an online community to foster political engagement. She discusses the 1996 case involving the Electronic Frontier Foundation (EFF), "a non-profit organization that defends legal rights in the digital world" (In der Smitten 37). The EFF protested against the U.S. Communication Decency Act and encouraged individuals who also opposed this act to upload a blue ribbon onto their personal or business websites (In der Smitten 37). As a result of the blue ribbon campaign, the U.S. Supreme Court deemed the Decency Act as unconstitutional. In addition to In der Smitten's findings, the article "The Writing on the Wall: A Content Analysis of College Students' Facebook Groups for the 2008 Presidential Election” by Juliana Fernandes et al. discusses social media's growing impact in a political realm: 
In the 2006 midterm Congressional elections ... candidates for U.S. Senate and House of Representatives were invited by Facebook ... to participate and host profiles like other users (Lariscy and Sweetser 180). At least one third of the candidates running for U.S. Senate seats responded to the invitation and posted their profiles on Facebook (Gulati and Williams 3). Moreover, in the 2008 presidential election, all Democratic and Republican candidates established Facebook and MySpace profiles, and hundreds of thousands of social network sites (SNSs) users added them as "friends" (Ancu and Cozma 570). (Fernandes et al. 654)

These references further underscore the ability of online media to serve as useful platforms for political discussion and activity. These three research studies contribute to an understanding of the intersection between politics, online media, and the use of rhetorical strategies.

The RSI model identifies three effective rhetorical strategies (attention, power, need) to implement within a social, cultural, or political setting. In the 1970s, communications theorist William Brown used Will Rogers, an American humorist and social commentator, as a source of inspiration to theorize the RSI model. In the 1930s, Rogers engaged in public speaking across the U.S. to provide insight on the topics of social persuasiveness and authority within a political environment. In his first book, Imagemaker: Will Rogers and the American Dream (1970), Brown discusses how Rogers used the ideology of the American Dream, "a U.S. ideology in which participants assume a more nearly perfect and ideal world can be achieved," as a type of rhetorical strategy in his speeches (Gring and Opt 231). After the publication of Imagemaker (1970), Brown was encouraged to "investigate the rhetorical processes by which the U.S. social system constitutes the ideology known as the American Dream, which had shaped Rogers' communicative interactions" (Gring and Opt 16). Brown's concern with how humans construct ideology and how ideological and social systems can be created, maintained, and changed led him to fully develop the RSI model into three distinct categories: attention, power, and need. 
Research that applies the RSI model shows that it is a relatively new yet workable theoretical lens to use for conducting a discourse analysis. In a 2009 study of Facebook group members' gratifications and their political participation, researchers identified four primary needs, an intervention of the RSI model, for participating in Facebook groups: socializing, entertainment, self-status seeking, and information (Park et al. 729). The analysis also revealed that informational uses correlated higher with political action than with recreational uses (Park et al. 729).

The RSI model's applicability to social and political action is reflected in the academic works of Mark Gring, a professor at the Texas Tech University. One of his articles, "Attention, Power, and Need: The Rhetoric of Revolution in Nicaragua," focuses on the revolutionary alliance between Marxism and Christianity in Nicaragua in the late 1970s. Although Gring explored all three interventions, his research revealed that the power intervention was most commonly used and came in the form of elitism and threat. However, during the Nicaraguan revolutionary events, individuals who were not associated with the revolution still exercised power in light of previous positions and connections (Gring 33). Since those with less stature still attributed trustworthiness to individuals who at one point had held prestigious positions, power can be tied to credibility. Christians often used abusive language to threaten those who were "less Christian" for not adhering to the religious beliefs of the status quo (Gring 33). The power intervention can encompass elements of hierarchy and elitism, which is an idea that is reflected in the works of other academics that apply the RSI model.

Similar to Gring, author Alberto Gonzalez applies the power intervention in his research in which he evaluates modes of public address at WMEX-FM, a radio station in Ohio. The station 
implemented the names "Mexicano" and "la gente," the latter meaning "the people" in French, to address the station's audience. Gonzalez notes that rhetorically, the use of "'la gente' deemphasized differences among community groups and amplified similarities by uniting their interests, inviting participatory behaviour without invoking ritual defense" (Gonzalez 407). His research illustrates that naming processes, an element of the power intervention, can function rhetorically to evoke certain perceptions and responses regarding social and cultural issues.

In addition to creating the perception of credibility, a type of power intervention, in their book Activism and Rhetoric: Theories and Contexts For Political Engagement (2011), Seth Kahn and Jonghwa Lee argue that North American perspectives play a significant role in the development and framing of issues related to the Middle East. Furthermore, framing issues rhetorically often comes in tandem with the sharing of personal experience to illustrate "the epistemic hegemony that currently limits what can and cannot be articulated in the public sphere about the current conditions under which Palestinians live in the West Bank and Gaza" (Kahn and Lee 116). An attempt to illustrate credibility is often evident in online political groups pertaining to the Israeli-Palestinian crisis in which individuals generate claims about their ideologies and offer personal narratives (Kahn and Lee 116).

Although the construction of credibility is often examined when being executed in an offline environment, the book Rhetoric Online: Persuasion and Politics on the World Wide Web (2007) by Barbara Warnick evaluates how the construction of credibility differs in a virtual environment. Warnick speaks of the loss of credibility when users generate comments online. The Internet's free-for-all ethos presents challenges for users to establish the expertise and trustworthiness of others, causing users to draw conclusions based on textual cues rather than 
author credentials (Warnick 47). Textual cues refer to the ordering of ideas, use of descriptive language, and deconstructing the text itself rather than having a stable print or material face-toface context (Warnick 47). Warnick believes in the power of credibility as a rhetorical strategy, but only individuals establish their reputation "by showing good judgment and a sense of good taste" when generating commentary online (Warnick 49). These insights contribute to an overall understanding of rhetoric use within a digital age.

A review of previous literature suggests that while constructing credibility in an online environment is a common rhetorical strategy, it can present challenges for users. Overall, rhetoric is highly relied upon to characterize the Israeli-Palestinian debate and online media are increasingly being used to promote political awareness and discussion amongst students. The RSI model is particularly applicable to analyzing the rhetorical strategies implemented throughout a social movement or issue such as IAW. A rhetorical discourse analysis performed using the RSI model can help to explore these new research areas, which illuminate four primary research questions:

1) How does rhetoric contribute to the formation and development of political dialogue and ideology amongst members of online groups?

2) In what ways is online credibility established in the IAW Facebook group?

3) What rhetorical strategies do group members implement online to incite, maintain, and/or subvert online social action?

4) How does the online rhetoric change over the course of IAW?

First, the link between rhetoric and ideology must be established in order to fully understand the underlying reasons for why members of the UWO group elaborate upon certain information but overlook other types of content. For instance, members may discuss one perspective but disregard another. Since individuals are inclined to perform actions and carry out behaviours that are consistent with their ideologies, an examination of the relationship between 
rhetoric and ideology will provide insight into how certain language constructions can be used to encourage or discourage certain forms of online action, discussion, and cultural relegation (Gring and Opt 18). A type of cultural relegation evident in the UWO group is racist ideology, which is one of the most naturalized ideologies and "is produced and reproduced through discourse. Language is the medium of a racist ideology and racist rhetoric is an important vehicle for the reproduction of most other racist practices" (Crenshaw and Roskos-Ewoldsen 275). This observation suggests that ideology is reinforced through language (rhetoric) and that rhetoric can turn ideology into practice.

As Warnick suggests, credibility is more challenging to establish in an online world. In online groups, group response towards certain commentary can encompass various forms: members can provide positive, negative, and neutral feedback, elaborate upon information, agree or disagree with certain viewpoints, or state that they are going to pursue or withhold action. Through examining the general group response towards the commentary of members who attempt to construct their credibility through exercising good judgment and taste, results may emerge regarding Warnick's assumption of this type of credibility as an effective rhetorical strategy. Since online credibility is an emerging area of research, exploring this particular question may lead to further conclusions about whether establishing credibility in this way is practical in an online environment.

In addition to credibility, examining how the overall rhetoric changes over the course of the event week can offer possible suggestions for how group members can engage in more wellrounded debate. Critiquing each RSI strategy within the UWO group and honing in on the rhetorical strategies that redirect the conversations and evoke the greatest member response may provide insight into the types of techniques that can encourage greater involvement and advance 
discussions in political Facebook groups. Overall, these insights will aim to promote an understanding of the use of rhetoric within a politically active online community to foster user engagement and discussion. 


\section{METHOD}

This study is a qualitative discourse analysis that examines the use of rhetorical strategies within user comments in the Facebook group UWO Students Against Israel Apartheid Week. This analysis is limited to the mission statement, rules, and comments that members post within the group. The primary unit of analysis for this project is an individual comment within the group. Each comment is treated as an independent unit of text rather than as part of a discussion. Throughout this analysis, the names of individual group members who produce comments have been changed for confidentiality purposes. These new names are marked with an asterisk (*). In terms of information accessibility and privacy, the content of the UWO Facebook group is made publicly available to all Internet users and thus, this research study did not require Research Ethics Board approval. The comments, mission statement, and rules were selected and copied into a document after IAW 2010. The comments were then sorted into one of three categories (attention, power, need) depending on the rhetorical strategy used to convey the comment. The total number of comments generated for each strategy was calculated to highlight any patterns and determine which strategy or strategies were implemented the most and which strategy or strategies were implemented the least. These observations can provide insight into the reasons underlying the success or failure of the discussions within the UWO group. For IAW 2010, the group features a total of 156 comments. In the group, four members each posted a death threat that they received to their personal email accounts during IAW. However, in light of the vulgarity and severity of the threats, these four threats were excluded from this analysis. After this screening, there were a total of 152 comments left in the group. To avoid any possibility of perceived bias within this study, 87 of those 152 comments were selected at random, grouped into one of the three RSI interventions, and analyzed via a rhetorical discourse analysis. The 
number 87 is significant because it represents a little more than half of the total comments to ensure a comprehensive data set. Furthermore, this number demonstrates a substantial and verifiable data set that is able to yield sufficient results from which conclusions can be drawn. The comments analyzed in this study were posted during March 1-7, 2010 (IAW for the 2010 academic year). The UWO group features comments from both IAW 2010 and IAW 2011.

The year 2010 marked the first year that IAW took place on the UWO campus (Rumleski). Although IAW 2010 is not the most recent apartheid event, the discussions within the group from IAW 2011 were not as heated and there was a lower participatory level amongst group members (total of 70 comments). Overall, the University Student Council (USC) possessed a dismissive attitude towards the type of rhetoric that was incited during online and offline IAW 2010 discussions. A Gazette article quotes Emily Rowe, the 2010 USC President. With respect to the UWO Facebook group, she stated:

There's nothing outlined in the USC constitution or bylaws that govern what we're supposed to do with media that's not directly related to the USC. In my opinion, we're here to represent students and make sure that all student voices are heard. We're an academic institution and we're not going to oppress someone's opinion or their freedom of speech. (Stone)

Although it is important for all viewpoints to be voiced, an exception should be made: commentary and discussions that may create an unsafe online or offline campus environment and make certain individuals feel threatened should be excluded from the discussion. Some of the oncampus behaviour and actions on behalf of the students such as the burning of Israeli flags contravene the codes of student non-academic conduct and the criminal code. These actions also produce a physically and emotionally dangerous environment. The prevalence of students using online media to characterize and promote the IAW 2010 discussion was recognized and thus in 
2011, the USC was more inclined to respond to media not directly related to the USC but that were still affiliated with the UWO academic institution.

Regardless of the differences between the 2010 and 2011 apartheid discussions, this study will track any changes in rhetoric and determine if any new rhetorical strategies emerge over the course of the event week. It also aims to highlight the most effective and ineffective rhetorical strategies to use in political Facebook groups. There are several theoretical orientations and terms that must be defined in order to provide the groundwork for this study. A thorough explanation of the RSI model will also demonstrate its applicability to this discourse analysis.

\section{The RSI Model}

The RSI model is useful to performing a rhetorical discourse analysis of text that conveys a political or social issue since this model combines aspects of the rhetorical, the social, and the interventional. The underpinnings of the RSI model stem from Aristotle's theory of rhetoric: "an ability in each [particular] case, to see the available means of persuasion" (Gring and Opt 11). A rhetorical act "attempts to nudge people and groups toward an interpretation of needs, relationships, and experience that we hope leads toward a particular social outcome" (Brown, Attention 26). This analysis is specifically concerned with Burkean rhetoric:

A function of language use, the use of words by human agents to form attitudes or to induce actions in other human agents. The persuasive aspects of language, the function of language as addressed, as direct or roundabout appeal to real or ideal audiences, without or within (Burke 44).

Since a message conveyed via text on a website may resonate with audiences differently than a message disseminated from a speaker in a video, the effect of rhetoric can change depending on the communicative context. 
The RSI model is "rhetorical because it involves communication, social because our rhetorical acts occur in interaction with other people, and interventional because these acts potentially shift the way in which we (and others) interpret and respond to experience" (Gring and Opt 4). These elements are specifically relevant to analyzing IAW since Facebook group members use certain tactics (rhetoric) in their online discussions with others (social) to frame the issue of Israel apartheid (intervention). Critiquing IAW through the RSI model is valuable because this annual event occurs in an attempt to instill a certain ideology: that global society should view Israel as an apartheid state. Since ideology and rhetoric form the underpinnings of the RSI model, this lens is relevant to evaluating the use of rhetorical strategies within this particular group. Furthermore, Gring and Opt define social intervention as "any act designed to encourage or impede certain kinds of behaviour or attitudes" (3). IAW and anti-IAW Facebook groups can be classified as a type of intervention because they promote or impede and contest or decontest the view of Israel as an apartheid state, encourage or discourage polarized attitudes of cultural and political groups, and foster or deter a safe campus environment. The UWO group encourages both offline and online forms of action such as filing in-person harassment complaints to the USC executive to promote a safe campus, encouraging attendance to lectures hosted by various student cultural groups and clubs, and suggesting the creation of online petitions.

The RSI model is divided into three distinct categories or interventions: attention, power, and need. 


\section{Figure 1: The RSI Model's Components}

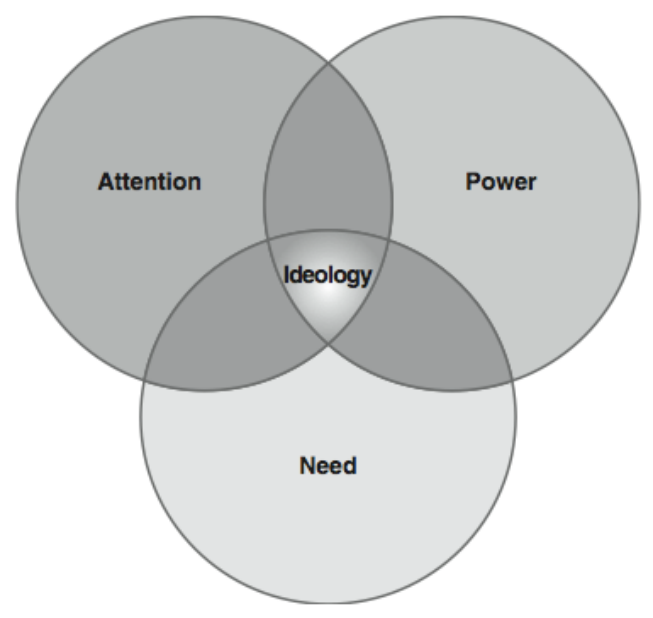

(Source: The Rhetoric of Social Intervention: An Introduction, 2009)

As Figure 1 represents, each intervention is rooted in the same ideology. Therefore, a change in the attention intervention can also cause a shift in power and need. For instance, an individual living in North America does not see the African AIDS crisis as affecting his or her life. However, after exposure to a television show pertaining to the crisis, the individual focuses his or her attention on the issue. This shift also creates a change in need (concern for people who suffer from AIDS) and power (AIDS organizations that can meet the need to end suffering) (Gring and Opt 18). These three interventions are rooted in a North American ideology.

\section{Attention}

The first intervention, attention, is defined as a "construction of ideology to create complex naming patterns to make sense of and interpret experience" (Brown, Ideology 133). According to Brown, through the use of rhetoric, attention can shift from one thing to another. Attention-shifting influences the way that humans create names and define their experiences. The process of naming relates to a later discussion of the power intervention. Attention-shifting is important because it "plays a key part in maintaining a community’s ideology" (Brown, 
Attention 17). Furthermore, efforts to prevent or delay a shift in attention can forestall social changes and reverse leading trends (Brown, Attention 22). A shift in attention occurs when an individual focuses on certain aspects of an issue (foregrounding) and downplays other aspects of an issue (backgrounding) (Gring and Opt 13). For instance, academic writing centres and leadership programmes are two factors that contribute to the university education system. However, some educators may shift attention to writing centers as a means of enacting a better university education system, backgrounding the use of leadership programmes. This intervention also uses metaphors and comparisons as rhetorical strategies. Brown believes that metaphor includes the alternation of appearance and reality. It is a matter of turning the tables and convincing others to "look at it this way instead of that way" (Brown, Attention 26). The attention intervention is a key rhetorical strategy because argumentative power resides in the ability to capture and focus audience attention.

\section{Power}

The second intervention, power, appeals to credibility and ethos to condition individual thought and action (Brown, Power 183). Brown refers to charismatic ethos as the most influential type of ethos (Brown, Power 183). Membership and reference to credible organizations can create the perception that the user can be trusted and thus is more likely to obtain their information from accurate sources. For instance, in the statement "I have been a longstanding executive member of the Toronto Humane Society," the speaker relies on his or her status and credentials to create feelings of trustworthiness among the receivers. The receivers may view the speaker as an expert and thus be more likely to accept their information as accurate. However, the tendency to overload the concept of power by equating it with influence 
overlooks other existing types of power that can cause notable outcomes without the elements of control, hierarchy, and elitism (Brown, Power 182).

The power intervention also consists of relational names, which "create power codes to shape participants' choices and behaviours" (Brown, Power 182). Relational naming processes are a type of power code and are generated in the form of adjectives. An example of a speaker using a relational name is, "I am civil." Brown refers to two types of relational names: reciprocal and complementary (Brown, Power 185). When individuals emphasize similarities between themselves and others, they create reciprocal relationships (e.g. friends and peers) (Gring and Opt 65). When individuals emphasize differences between themselves and others, they create complementary relationships (e.g. parent/child and winner/loser) (Gring and Opt 65). A social hierarchy is formed when these relational names are implemented because they imply a degree of equality (reciprocal names) and inequality (complementary names) amongst individuals. Relational names are closely linked to ideology, which looks "not at the content of ideas, but their function, which tap into emotion and form the spiritual-intellectual foundation of group cohesion or solidarity" (Brown, Ideology 135). An ideology is essentially a value or belief system that an individual or group possesses. Ideologies consist of certain concepts that are created, maintained, and subverted over time. Each ideology possesses core concepts, which can gain or lose importance to an individual or group depending on the social context. Political Studies professor Michael Freeden provides a unique definition of ideology:

The relative "success" of an ideology depends on its ability to impose the belief that its own conceptual definitions are the "correct ones." Each ideology performs a continuous decontestation of its concepts - it tries to eliminate all possible contestation of its own conceptual definitions, thereby rejecting competing definitions. (Freeden 14) 
Since ideology arises out of naming processes, which occur in the power intervention, and each intervention affects the other two simultaneously, social systems such as online media platforms can help to construct ideology (Gring and Opt 19). Individuals implement the power intervention to sway individuals' opinions and condition others to accept a prevailing ideology. An example of a power intervention is Orientalist thought, which cultural literary theorist Edward Said defines as the idea that the Western world marginalizes Arab culture in historical texts, pop culture, and politics (Said 31). Orientalists use relational names to label Arabs as cunning, suspicious, and functioning only in conflict situations in both media and social contexts (Said 38). This marginalization also identifies the Arab subject as an Other: an individual that is viewed through a critical lens and devalued in light of their cultural difference (Said 48).

Orientalism is a type of ideology represented in the UWO group that is specifically rooted in the power intervention of the RSI model. The power intervention is the most influential since ideologies and preconceived notions are often so deeply entrenched within the individual that they cannot be completely subverted.

\section{Need}

The last intervention, need, is connected to the power and attention interventions. Attention-shifting occurs when different types of needs are stressed. Needs are divided into two categories: biosocial and symbolic. Biosocial needs are innate needs such as the need for water (Brown, Need 4). These needs are expressed in communication. On the other hand, symbolic needs are constituted by communication such as needing Evian brand water because advertising suggests that it is healthier to drink than tap water (Brown, Need 7). In this way, communicative practices can influence ideology and, in turn, how individuals interpret their needs. Individuals can focus attention on both individuality-stressing needs and collectivity-stressing needs. 
Whereas individuality-stressing needs are centered on using the pronoun "I" to describe an attitude, collectivity-stressing needs rely on the pronoun "we." Individuality-stressing needs focus on the individual such as when a student decides to study in order to perform well on a test instead of attending a fundraising event to raise money to build a homeless shelter (collectivitystressing need). Through distinguishing between these needs, "we open and close communication channels in response to need advocacy" (Gring and Opt 62). Communication channels are opened when an intervener, an individual who is able to separate themselves from the collective group and look at the larger picture, is present. These individuals exercise autonomous thinking and take on a leadership role by devising methods to solve the problem and thus meet the group's needs (Brown, Need 10). Those who can potentially satisfy group needs are referred to as need-meeters (Gring and Opt 61). For example, since the Israeli-Palestinian conflict influences the cultural and religious beliefs of many students, university student bodies, or need-meeters, created IAW to respond to the student need for an outlet to voice their political perspectives. An intervener is a type of rhetor: an individual who implements rhetoric and rhetorical strategies in either their language or actions. Interveners are sometimes viewed as deviants since they can oppose normative practices and ideologies. Deviance is amplified when there is an increased advocacy of needs. Brown notes that as individuals open and close attention to others for need advocacy, there is a shift in competitiveness and cooperativeness (Brown, Need 4). When deviance is compensated, needs appear to be satisfied.

Although the three interventions are not mutually exclusive, they can also be treated as separate; power and attention can be implemented at the same time but power can also exist without the presence of attention (Gring and Opt 19). Interventions are significant to social and cultural issues because they imply a "mediating relation between the rhetor's act and ongoing 
action of the audience" (Brown, Power 185). The three interventions of the RSI model -attention, power, and need -- can be used as rhetorical strategies to construct, maintain, and subvert ideology amongst individuals. Since ideology forms the foundation of the RSI model, this lens is valuable for an analysis of IAW: an event intended to promote new political ideologies of Israel. The RSI model's three interventions are evident in user comments posted in the Facebook group UWO Students Against Israel Apartheid Week. 


\section{RESULTS AND DISCUSSION}

Prior to examining the members' comments within the UWO Students Against Israel Apartheid Week Facebook group, a rhetorical discourse analysis of the group mission statement, which incorporates a set of rules that all group members are expected to follow, will provide insight into the type and style of the subsequent arguments that the members present.

\section{Group Mission Statement}

A group for students who don't want to see hate and lies spread around campus.

If you're a supporter of Israel, or simply against the spread of hatred and propaganda, this group is for you. Let's show support against this terrible event and make the USC know that it is not welcome on our campus ever again.

\section{Group Rules}

In response to many comments being made within the group from both sides of the IsraeliPalestinian debate, all content that has been posted that does NOT have any relevance towards IAW has been removed.

If anyone has comments relating to IAW and NOT Israeli policy OR Palestinian policy, it will be gladly welcome.

Content that is not related to the group's intended purpose (see group description if the title alone is not clear enough) will be removed, and if continued by the same individuals, they will be removed from the group. Let's hope it doesn't come to that.

A rhetorical discourse analysis of the group mission statement suggests that the creator of the mission statement uses attention-shifting to background the specific case of pro-Israel students and foreground the more holistic topic of students who are "simply against the spread of hatred and propaganda." However, the name of the group, UWO Students Against Israel Apartheid Week, implies that the group is directed specifically towards discussions pertaining to the fate of Israel. By using relational naming processes to label IAW as a form of hatred and a type of propaganda, two general categories that are more likely to appeal to a larger audience, the 
group creator shifts attention away from the specifics of Israeli politics in order to influence the group's popularity. In this way, shift in attention is an effective rhetorical strategy that can be used to boost group membership. Although the group may feature high membership (425 members) compared to other social and political UWO Facebook groups (Best Buddies UWO Chapter - 39 members, Solidarity for Palestinian Human Rights at UWO - 74 members, UWO Conservatives -184 members), the rhetoric used to convey the mission statement does not encourage members to educate themselves and pursue action. According to the National Opinion Research Centre (NORC), a mission statement is intended to:

Tell the community why you exist. It is a set of value statements that set the tone for your program, while motivating and unifying all partners. A mission statement conveys the program's purpose, what you are hoping to achieve, and the principles that guide the work (NORC).

Since the UWO group mission statement is non-specific and does not feature any collective objectives and outcomes, it does not respond to the collectivity-stressing student need to counter IAW and promote a safe campus via online media. The NORC vision of a proper mission statement suggests that the UWO group mission statement does not possess key components such as motivational tactics and thus falls short of useful expectations.

Similar to a rhetorical discourse analysis of the group mission statement, a critical evaluation of the group rules illustrates the group creator's employment of the power intervention of the RSI model. The rules stress the importance of members generating comments that are relevant to the Israel apartheid discussion: "all content that has been posted that does NOT have any relevance towards IAW will be removed. If continued by the same individuals, they will be removed from the group." Although this relevancy rule is implemented in an attempt to maintain a focused discussion amongst group members, the elimination of certain members 
and commentary does not reflect Jürgen Habermas' vision of inclusive public debate and a healthy public sphere in which all individual ideas are represented equally whether deemed relevant or irrelevant (Habermas 89). Author Elisabeth Gareis, who is noted for studying group work and formation, believes that Habermas' ideal speech situation is the foundation for collaborative group experiences. There are four conditions for ideal discourse to occur:

No one capable of making a contribution is excluded, participants have equal voice and equal chances to make arguments, participants are honest with each other and with themselves (i.e., they assert only what they truly believe), and there is no coercion built into the process (Gareis 166).

Gareis advocates that a group will only achieve a desirable outcome if all members are included, there is no coercion, and each member's opinion is freely stated (Gareis 167). Gareis would argue that the use of reciprocal relational names, coupled with the social hierarchy of equality that they create, would foster a healthy public sphere. She would also suggest that since the UWO mission statement and rules oppose Habermas' ideal speech situation, the group has a reduced likelihood of producing well-rounded, informative discourse. The ideal speech situation illustrates that irrelevant ideas do not impede productive debate since individuals are able to utilize their collective agency to eliminate poor ideas, thus enabling the emergence of valuable perspectives. This ability is depicted in the UWO group when members collaboratively challenge and counter opinions that they view as uninformed.

These analyses provide insight into the significance of implementing a constructive mission statement in an online political discussion group. A mission statement is important because it sets the tone, context, and framework for the arguments and debates that follow within the group (NORC). The hierarchical, exclusive manner in which the mission statement and rules are conveyed incites a similar discourse that characterizes the group comments. Therefore, group 
creators must pay closer attention to the way in which they construct the mission statement and rules so that the conduct of a proper debate can follow.

Using the RSI model to analyze the group comments illuminates the interventions of need (for a more powerful mission statement and an event week for anti-IAW activists), power (employment of Orientalist thought and credibility), and attention (towards the various ideologies that underlie IAW and comparisons to South Africa's apartheid movement).

\section{Textual Discourse Analysis}

The following discussion features samples of comments from the UWO group that fall within the attention, power, and need interventions of the RSI model. The individual comments are embedded within the discussions (i.e. textual discourse analyses) of the Facebook data. The data will be examined in terms of each RSI intervention in the following order: attention, power, and need.

\section{Attention}

An analysis of the UWO group's user comments reveals several patterns and instances of attention-shifting. These shifts in attention are characterized by the use of comparisons, metaphor, foregrounding, and backgrounding. The comment "a person chooses where they get their information and which 'facts' go in and which don't and if you wanna play the fact game we can play "till we are blue in the face" underscores the ease of creating a shift in attention amongst group members. Since individuals possess the agency to choose "which 'facts' go in and which don't," selective perception is common especially when discussing the IsraeliPalestinian conflict. Since no two individuals encounter and interpret information from the same outlets, at the same time, and in the same order, there is often a discrepancy when individuals present their version of the facts to characterize an account. Today's plethora of news and media 
outlets signifies a high volume of information, which allows for the emergence of new perspectives. Although young adults may be less likely to obtain news from traditional news media outlets such as radio and cable news networks, their youth does not indicate that they are less politically informed than older adults (Kohut 3). The integration of social networking sites such as Facebook, a youth-dominated medium, with political information has the potential to encourage youth to seek and encounter information from less common news outlets. Despite Kohut's findings, as the pool of information increases, so does the possibility to create more attention shifts that are directed towards the new information being generated. In this way, a shift in attention can be created without much difficulty.

The following comments depict a similar shift in attention, but a shift from the true mandate of IAW:

By referring to "Jewish gangster" as you did in one of your earlier posts, you are not only provoking people, but you are making a broad statement about Jews - not about the politics of a country. If you really want to help and raise awareness, joining the group that feels that this event spreads hatred against Jews (even if you disagree) and writing comments like these is probably not the best way to go about it. I believe that there is a clear distinction between being pro-Palestinian and anti-Israel. You are crossing that line.

"Israel's critics continue to hurl the apartheid epithet at the state when they have to know, or they ought to know, that it is a calumny. Interestingly, they do not use it for Saudi Arabia, which maintains as perfect a system of gender apartheid as can be imagined -women can't even drive, never mind vote -- or elsewhere in the Arab world, where Palestinians sometimes have fewer rights than they do in Israel." Perhaps Israel is being shown in an unfair light. This event truly is anti-Semitism under the guise of false "antiIsrael" claims. The Arab world's mistreatment of Palestinians is often far worse than that of the alleged crimes Israel commits. Saudi Arabia is indisputably more of an apartheid state that the accusations against Israel. It's time this event be called out for what it is - a hate fest, and any reasonable person, regardless of faith or conviction should be able to see that.

Interveners generated the above comments to argue that IAW is an event that "spreads hatred against Jews" and is "anti-Semitism under the guise of false 'anti-Israel' claims." The first 
comment seeks to redress or refute the metaphor of an Israeli as a "Jewish gangster." The relational name, "gangster," coupled with its enclosure in quotation marks, is significant because it illustrates the array of speech acts that are primarily used within the UWO group - threats, insults, and sarcastic jokes. Furthermore, direct quotations are often used in an online environment to "make a mere viewpoint seem authoritative rather than personal," "show that what is reported is an unconvertible fact," and "indicate the political bias" (Obiedat 275). The second comment uses a direct quotation from an unknown source. It also illustrates a bias towards Israel by discussing the severity of the "Arab world's mistreatment of Palestinians" and referring to IAW as a hate fest. The first comment also exemplifies a pro-Israel bias, which is evident in many of the group comments, and is largely attributed to the idea that critics of IAW often support Israel, its people, and its endeavours. Therefore, a group dedicated to overturning IAW will likely include members who are pro-Israel. Since many of the group members are also of Jewish descent, they may be more inclined to think that their group is being targeted. Thus, the focus turns from discussing apartheid to the criticism that global society analyzes Israeli practices through an anti-Semitic lens. However, this common accusation is not necessarily unfounded. Many individuals believe that IAW is anti-Semitic because a substantial portion of the Israeli population (76\%) is of the Jewish religion (North American Jewish Data Bank). In light of Israel's significantly large Jewish population, many individuals are inclined to make the generalization that an act targeted against Israel is an act targeted against the Jewish people. However, the first comment highlights that there is a clear distinction between an individual who is pro-Palestinian and an individual who is anti-Israel. Since the group does not provide fleshed out definitions for what comprises pro-Israel and anti-Semitic attitudes, there is an increased likelihood of group members misinterpreting the nature of the event week and using the wrong 
definitions to characterize the issues at stake. Therefore, a shift in attention, which both foregrounds and backgrounds certain classifications and information, may restrict members in their ability to create possible solutions to resolve the issue both on and off campus. The following comment also attempts to foreground instances of Arab-Arab apartheid to background the severity of Israeli-Arab apartheid:

What about the "brutality" Palestinians face at the hands of other Arabs? In Lebanon, there are over 60 jobs Palestinian refugees are forbidden to have. It's black and white man - that is a fact. What about the horrible treatment of Palestinians in places like Saudi Arabia, where they are treated as second-class citizens at best? What about the fact that within Israel proper, everyone is treated equally? There are all facts.

In addition to a focus on distinguishing between pro-Palestinian and anti-Israel mentalities, the comments in this group include comparisons between Israeli apartheid and the South African apartheid movement from the 1940s until the early 1990s. The foregrounding of how Israeli apartheid differs from South African apartheid, a former apartheid state that received world condemnation, reinforces the group's political ideology that Israel is not guilty of enacting apartheid practices. In this respect, shift in attention through comparison is an effective rhetorical strategy because it provides members with information that discounts the apartheid accusations against Israel. The creator of the following comment implements the rhetorical tactic of comparison:

We have to remember that during apartheid in South Africa, there were no black suicide bombers. There were no kidnappings of South African soldiers. Whites were not portrayed as dirty animals and black children were not trained to despise and hate whites. There were no calls by blacks for South Africa to be destroyed or for whites to be pushed into the sea.

The above comments illustrate that the use of comparisons within commentary are centered around distinguishing between apartheid and non-apartheid states, the Eastern and 
Western worlds, Arab-Arab and Arab-Israeli apartheid, and the lifestyles, values, and political affiliations of Arabs and Israelis living in Israel.

An analysis reveals that the group comments feature attention-shifting when members evaluate the various ideologies that underlie IAW and when comparisons via metaphors are drawn between Israeli and South African apartheid. Since the group mandate opposes IAW, shifting attention towards a former, world-condemned apartheid state is an effective strategy that reinforces the group's political ideologies and provides them with a stronger argument. However, this strategy can also cause members' discussions to divert from evaluating the root causes of the Israeli-Palestinian conflict and their segregation issues.

\section{Power}

Since the three RSI categories, attention, power, and need, are all rooted in the same ideology, there are several repetitions of comments within the three classifications. The following discussion features samples of user comments from the UWO group that fall within the power intervention of the RSI model.

An analysis of the UWO group comments reveals several patterns and attempts to establish credibility (appeal to ethos), relational naming processes, and Orientalist thought. These three elements are types of power interventions because they use rhetoric to shape ideology. Several of the comments such as "60 jobs that Palestinians are forbidden to have" and "Qassam rockets contain up to $10 \mathrm{KG}$ in explosives" do not succeed in attempting to generate factual information to establish credibility and build logical arguments. The sources of this information are never referenced, which raises the question of whether members are engaging in thorough fact-checking processes before making their claims. Members are also often inclined to establish their credentials before stating their opinions and viewpoints in order to create the perception that 
they are knowledgeable and can be trusted. For instance, in the comment "unlike you, I lived in Israel 18 years. I have a pretty great picture of what's going on inside," a group member uses the power intervention by stating that she had lived in Israel for most of her life and thus is able to expand her perception beyond North American ideology. She also uses the power intervention when she writes, "luckily my native language is Hebrew and I also happen to know some Arabic, so I have a clue about 'Semitic"' to illustrate her academic knowledge of the Arabic language, which allows her to truly understand the meaning behind the word "anti-Semitic." The member attempts to establish her credibility but in an illogical way because of language barriers; knowledge of a language and the ability to define certain terms within that language are not tantamount to certain terms signifying the same idea within another language or culture. In the case of the above comment, "anti-Semitic" may be defined differently in Arabic than it is in English. This example also shows the overlap between the RSI model's interventions. In addition to the power intervention, the discussion of the term "anti-Semitic" exemplifies a shift in attention by reframing IAW in terms of anti-Semitism when it is intended to foreground apartheid.

In addition, the following comments feature members who attempt to appeal to ethos by referencing their previous and prestigious academic titles:

Take this from a University Student Council (USC) veteran (past social science councillor and Israel on Campus (IOC) President). A USC sanctioned club cannot deny access to Western students because they disagree with them, also denying the right for a participant to ask a civilized question would be in contravention to USC clubs policy. I was a USC Social Science Councilor for two years, President of the Israel Action Committee (now the IOC) and a member of the USC Clubs Policy committee. One of the best things that you can do right now is tell the USC how you feel and, as a concerned student, how this event is affecting you (i.e. makes you feel intimidated, unsafe, etc.). 
By referencing his former USC veteran title, this member creates a complementary relational name between a recognized UWO student and an average UWO student. By attempting to assert his status through the creation of complementary names, the member relies on his elitism to incline members to give more weight to his opinions than to those of other group members. Although no members admitted to filing a complaint or pursuing action after this comment was made, members of the group advanced the conversation within the group setting and agreed with his viewpoint. However, in contrast to the general pattern of response, the lack of group response to members with credentials indicates that reference to an academic title is not sufficient to coerce members to adopt an ideology or perform a certain action. The comment "I was a USC Social Science Councilor for two years, President of the Israel Action Committee (now the IOC) and a member of the USC Clubs Policy committee. One of the best things that you can do right now is tell the USC how you feel and, as a concerned student, how this event is affecting you (i.e. makes you feel intimidated, unsafe, etc.)" exemplifies appeal to ethos (President of IOC) paired with the generation of a sensible solution (report to the USC). Therefore, in order to effectively use rhetoric to incite action amongst group members, comments that use appeals to logic and rationality are essential. These appeals are commonsensical and encourage members to utilize their student autonomy and offline resources. On Facebook, users possess the power to report comments that they do not like, that are harassing to themselves or to a friend, are spam or scams, contain hateful speech, violence or harmful behaviour, or are sexually explicit (Facebook). However, there is no tool that enables users to report the legitimacy of certain user comments. This restriction signifies that group member attempts at constructing credibility on Facebook are often left unchallenged. 
The credibility of members who join the group for the purpose of disagreeing with the prevailing ideology is often undermined by those who feeling strongly about Israel as an antiapartheid state. For instance, in the comment "I think our good friend Adam's* credibility can be summed up in the following: he just referred to Qassam rockets as 'non-explosive.' Qassam rockets contain up to $10 \mathrm{KG}$ in explosives," a member of the group attempts to overturn Adam's* credibility regarding a statement made about the explosiveness of Qassam rockets. Although the member offers information that differs from Adam's* perspective, he does not offer a source to support his rebutting point that the rockets are indeed explosive. A discourse analysis of comments of this nature suggests that criticizing a member's comments in a public domain can function in two distinct ways: it can instill feelings of insecurity within the member regarding their statements and opinions, or it can encourage the member to engage in more thorough fact-checking processes. The type of language that the member uses to undermine Adam's* credibility is reflective of the tone used to convey the group rules and mission statement: exclusionary and hierarchical. Contemptuous language in its various forms is usually an expression of the power intervention.

In addition to establishing credibility, the following comments illustrate how Orientalist thought exemplifies the RSI model's rhetorical strategy of power through relational naming:

"Israel's critics continue to hurl the apartheid epithet at the state when they have to know, or they ought to know, that it is a calumny. Interestingly, they do not use it for Saudi Arabia, which maintains as perfect a system of gender apartheid as can be imagined -women can't even drive, never mind vote -- or elsewhere in the Arab world, where Palestinians sometimes have fewer rights than they do in Israel." Perhaps Israel is being shown in an unfair light. This event truly is anti-Semitism under the guise of false "antiIsrael" claims. The Arab world's mistreatment of Palestinians is often far worse than that of the alleged crimes Israel commits. Saudi Arabia is indisputably more of an apartheid state that the accusations against Israel. It's time this event be called out for what it is - a hate fest, and any reasonable person, regardless of faith or conviction should be able to see that. 
Hamas values death, Israel values life. So while Hamas puts all the money they get into more weaponry, and more ways to increase their own civilian casualties to wage a PR battle against Israel, to inspire delusional, ignorant, bigots like you, Israel has built shelters, siren warning systems, and is working on defense missile systems to protect its own people.

According to Orientalism, the Western world possesses preconceived notions of the Middle East as corrupt, barbaric, and functioning only in conflict situations (Said 38). These relational names reinforce Western conceptions of the Other. For instance, the second comment uses relational names to label Palestinians as "delusional, ignorant bigots." The first comment refers to the restrictive gender policies of Arab nations such as Saudi Arabia. The member states, in the Arab world, “women can't even drive, never mind vote." Although this broad statement is not true of all Middle Eastern countries, it supports the Western perception of how women are generally treated in the Arab world. The analysis revealed that since a politically active member of IOC produced the first comment, their insights were given more weight and feedback since this individual is well-known throughout campus. Therefore, on-campus political affiliations and associations act as a stimulus for group member support.

In addition to the first comment, the second comment plays upon Orientalist thought to articulate political ideology. The second comment suggests that Israel protects its people whereas Hamas, the Palestinian political party that governs the Gaza Strip, is concerned with suicide bombers and establishing weaponry. Comments that evoke Orientalist ideology through comparisons, which equate Palestinians with terrorism, attempt to gain support for a side that is anti-Palestinian (i.e. pro-Israel and anti-IAW). The second comment uses the complementary relational name between Hamas and Israel, where Israel is labeled as superior for its philanthropic acts of providing humanitarian aid to its neighbouring territories. 
Similarly, the comment "I guess that's where the difference between IOC and PalSA lies. IOC (and probably most other clubs on campus) welcomes everyone to their events, including pro-Palestinians. IOC encourages discussions, questions, and debates" draws comparisons between two prominent and opposing UWO student associations: the Palestinian Student Association (PalSA) and Israel on Campus (IOC). The complementary relational name is developed between IOC and PalSA. Since there is limited use of reciprocal relational names within members' commentary, a social hierarchy of inequality and elitism is formed within the group. Whereas most Islamic and Palestinian students support PalSA, most Jewish and Israeli students support IOC. This comment positions IOC in a positive light and PalSA in a destructive light by suggesting that IOC is a more inclusive, productive student association. Walter Lippmann's observation in his book, Public Opinion (1922), illustrates how Orientalist thought is an effective rhetorical strategy. He states, "whatever we believe to be a true picture, we treat as if it were the environment itself" (Lippmann 4). His idea signifies that although people possess certain beliefs and preconceived notions of cultural groups, stereotypes must be merely prodded in order to be activated and carried into the external environment. This observation exemplifies the power of rhetoric to articulate an ideology. Therefore, the UWO group's promotion of Orientalist thought, a type of power intervention, generates more harmful perceptions of the Other. This standpoint encourages UWO students on Facebook to join groups that promote views that differ from those of Palestinians (i.e. anti-IAW perspective).

The following comments utilize personal narratives to voice certain perspectives: 
I went to the booth and asked if they thought it was counterintuitive to suggest that the 2 nations shouldn't be divided but to suggest that there should be a 2 state solution. I told them again and again I wasn't looking for an argument but rather for information. They told me I was uneducated and brought up other issues. I kept telling them I wanted an answer and that I didn't want to argue and the other issues are irrelevant. Only one girl would address what I asked, the rest were aggressive, out of line, and were looking to start a fight. That is not an information booth at all - it is an outlet for them to invoke argument. If it was an information booth, they would have answered my question and not have bombarded me with other issues. For some reason they said that the separation had nothing to do with apartheid, but were apparently protesting against the separation yesterday.

I went to the PalSA lecture today at the UCC and at first they were hesitant to let us in. It was not until we agreed not to cause any disruptions that they decided to let us join the discussion. However, what really struck me as upsetting the most was when we tried to get some answers from their group. My friend Sam* went to ask a question, and was immediately interrupted, as the guard told us that he was not to speak unless we asked a question, which he attempted to. I felt that this was incredibly rude and discriminating, as the people who were pro-Palestinian were given full attention, while we were interrupted. This behaviour was incredibly disrespectful and insulting to us as Jewish students on campus.

In the first comment, the group member recalls their interactions with members of PalSA during IAW. Throughout the event week, PalSA ran an information booth in the UWO student centre to answer questions and to educate students about the mandate of IAW as well as their overall standpoint on the Israeli-Palestinian debate. The descriptions in this comment suggest that the UWO group member did not have a pleasant experience; he was unable to ask questions, obtain information, or engage in thoughtful discussion with the PalSA members. This experience led the UWO group member to characterize the general nature of PalSA members as rude, aggressive, and dismissive, which are relational names that exemplify power codes.

The second comment reflects a similar experience. A Jewish UWO group member did not feel welcome to one of the PalSA lectures provided during IAW. When attempting to pose a question, her friend Sam* experienced difficulty and felt that the Palestinian students were given 
preferential treatment. The rhetoric used in these anecdotal accounts influences conceptions of the Other and creates the idea that PalSA is one-sided in their debates. Illuminating first-hand accounts that exhibit PalSA's narrow mindset can encourage UWO students to question the overall integrity and comprehensiveness of PalSA's arguments, specifically their viewpoint of Israel.

An analysis reveals that when the power intervention of the RSI model is used, group members attempt to establish credibility, primarily use complementary relational naming processes, and promote an Orientalist mentality. The most common way that group members attempt to establish credibility is through referencing their previous academic titles such as USC President and Social Science Councillor. However, a lack of group response to comments posted by members who establish credibility in this way illustrates that this method is not sufficient to instill political ideology and incite action in an online group. Orientalist thought is reinforced through group members' anecdotal approaches to convey their experiences, which generate certain Palestinian stereotypes. This strategy helps to build and reinforce the anti-IAW case. In addition to the power intervention, the need intervention is employed to raise awareness of certain issues within the group.

\section{Need}

The following discussion features samples of user comments extracted from the UWO group that fall within the need intervention of the RSI model.

An analysis of the comments in the UWO group suggests that there are two primary needs within the group: the need for the other side to be represented (an Islamic State Apartheid Week) and the need to reevaluate the group mission statement and rules. All of the needs represented in the UWO group are symbolic because they are expressed through communication. 
An overall analysis of the group commentary suggests that there were no biosocial or innate needs represented.

The following comments underscore the symbolic need for "public condemning of Arab states and their treatment of Palestinians," suggesting that Arab-Arab apartheid is downplayed at the expense of critiquing Israeli-Arab apartheid:

The fact remains that I don't see any public condemning of Arab states and their treatment of Palestinians - only Israeli.

If you want to hold a week to condemn Israel, its government, and its people, then we should have a week condemning the other side as well. Or better yet, instead of pointing fingers and spreading hatred, let's focus on what can be done from this point on.

Hosting an event that entails the "condemning of Arab states" and "condemning the other side" will provide students with the opportunity to evaluate both the Arab-Arab and Israeli-Arab apartheid situations to satisfy both parties. Furthermore, the rhetorical implications behind incorporating the word "education" into the event week's title would illustrate that the event's mandate is to inform students about apartheid - not to argue about the implications.

Similar to the need for the other side to be represented, the group comments illustrate the symbolic need for a clearer mission statement. In the comment "this group is not an IsraeliPalestinian conflict-solving group. It is a group that is against Israel Apartheid Week," the group member was required to clarify the mandate of the group, which implies that there was a shift in attention. The comment "the group you are currently writing on is a group focused on the event known as Israel Apartheid Week. Obviously you will have your opinion and I will have mine and little that either of us will say is going to change each other's opinion" implies a similar type of shift in attention on behalf of another group member. Since some group members express 
feelings of uncertainty and clarification is sometimes required, there is a need to reassess the mission statement and focus of the group. The comment in which the member attempts to clarify the mandate of the group also advocates that the rhetoric used to convey the mission statement should be reevaluated in order to ensure that it resonates properly with all group members.

The comment "what's happening to this group? The purpose of it was for us to promote a safe campus for ALL students and we think that an event such as IAW doesn't allow for that" attempts to focus the discussion within the group. The creator of this comment identifies the need for the group to revisit the mission statement, which advocates for the destabilization of IAW. This comment was made in light of the revelation that group members were discussing topics irrelevant to apartheid. Therefore, a shift in attention that is too drastic can undermine the group's ability to accomplish their goals. There is a need for comments such as the comment above to bring the conversation back to the heart of the debate in order to facilitate an appropriate discussion. Thus, the need intervention functions as an effective rhetorical strategy by encouraging members to return to the mission statement. As advocacy towards need-meeters increases, so does the openness and responsiveness to other members of the group. Since the creator of this comment is viewed as a need-meeter within the group, communication channels between other group members were opened and collaborative discussions arose over the implications behind the mission statement.

Similar to this comment, the creator of the comment "the videos you posted in the last few days here do not follow the group's rules and should be deleted" is viewed as a need-meeter. This comment illustrates the constraints that group members may impose if the group rules are not followed. The member suggests that in order to follow the group rules, videos posted in the 
group that touch upon Israeli and Palestinian policy should be deleted. This need-meeter increases need advocacy by attempting to fulfill the symbolic need of group compliance with the mission statement. However, since the group rules impede the delivery of certain commentary (need advocacy), communication channels between individuals became closed. This observation opposes a key aspect of the need intervention: increased need advocacy opens communication channels. This comment depicts a collectivity-stressing need to reinforce the group rules. An analysis of the above comments illustrates that the rhetoric implemented through the need intervention can be valuable because it can encourage members to rethink the purpose of the group and the manner in which the mission statement and rules are conveyed. However, the need to reiterate the mission statement and rules suggests that they must be devised more clearly and powerfully.

A rhetorical discourse analysis of the comments reveals a need for a week that critiques all Middle East apartheid practices as well as a need for a clearer, more powerful statement. The group features a limited number of comments that highlight a diversion from the mission statement and rules. Comments that implement the need intervention can encourage members to produce more valuable discourse in their discussions. After the question "what's happening to this group?" was posed, members produced less insulting and demanding commentary in their subsequent discussions. Thus, if one individual illuminates the idea that members are losing focus of the discussion and are constructing hostile discourse, it can incite the rest of the individuals to reflect upon the nature of their comments and thus put more thought into the construction and content of their arguments. However, individuals may be less inclined to stress individuality-stressing needs because they may not feel that they have the grounds to correct other group members in their commentary. Research on social and heuristic approaches to 
acceptance of information in online environments suggests, "while digital media and information abundance may complicate people's confidence in and knowledge of who is an authority, electronic networks and social computing applications make it easier to harness collective intelligence to assess and evaluate information and sources online" (Flanagin, Medders, and Metzger 4). Flanagin, Medders, and Metzger's view of collective intelligence implies that social networking sites such as Facebook, a type of social computing application, represent a rhizome, peer-to-peer network. Since Facebook includes a notion of groupism in their mandate to "give people the power to share and make the world more open and connected," assuming an individualistic mentality within Facebook groups may be out of line with the Facebook structure (Facebook). Comments that clarify the group mandate and advocate for an Islamic State Apartheid Week reflect collectivity-stressing needs and attempt to express the status quo opinions of the group. Since the UWO group is comprised of a collection of members, it is expected that collectivity-stressing needs highly characterize the group. There are few comments in the group that reflect individuality-stressing needs. Comments that reflect personal opinion and leadership ("you will have your opinion and I will have mine" and "what's happening to this group?") are unique to the group because they represent individual-stressing needs, which are not typical in group settings. 


\section{General Analysis}

Table 1 contains the total number of RSI strategies implemented during each day of IAW:

Table 1: The Total Number of RSI Strategies Implemented During IAW

\begin{tabular}{|c|c|c|c|c|c|c|c|c|}
\hline & $\begin{array}{c}\text { March } \\
1\end{array}$ & $\begin{array}{c}\text { March } \\
2\end{array}$ & $\begin{array}{c}\text { March } \\
3\end{array}$ & $\begin{array}{c}\text { March } \\
4\end{array}$ & $\begin{array}{c}\text { March } \\
5\end{array}$ & $\begin{array}{c}\text { March } \\
6\end{array}$ & $\begin{array}{c}\text { March } \\
7\end{array}$ & $\begin{array}{c}\text { Total } \\
\text { Comments }\end{array}$ \\
\hline Attention & 1 & 3 & 7 & 15 & 1 & 4 & 2 & 33 \\
\hline Power & 6 & 1 & 9 & 7 & 4 & 2 & 4 & 33 \\
\hline \multirow[t]{2}{*}{ Need } & 3 & 1 & 6 & 5 & 2 & 1 & 3 & 21 \\
\hline & & & & & & & & 87 \\
\hline
\end{tabular}

The data in Table 1 yields three main conclusions. First, the attention and power interventions were relied upon equally, totaling 33 comments each over the course of the week. A shift in attention was implemented the most during the middle of Apartheid Week (15 comments on March 4). A possible explanation for this finding is that by the middle of the event week, students have had the opportunity to get the main issues out onto the table. By this point in time, a significant amount of information and number of opinions have been generated and this abundance can cause members to become sidetracked in their thinking processes.

Based on the random sampling of comments ( 87 out of the 152 total), the power intervention primarily characterizes the comments posted on the first and last days of IAW. However, the type of power intervention used changes over the course of IAW. At the start of the week, appeal to ethos was most commonly used. However, Orientalist thought, conveyed through relational naming, reached its peak during the middle of the event week (March 3-4) 
and then diminished as the week progressed. On February $28^{\text {th }}$, the day before IAW began, a group member stated, “the Palestinians don't even know what they're talking about. They're uneducated and their thoughts are garbage." Since members of the UWO group possessed preconceived notions of Palestinian UWO students before the event week even commenced, it was expected that Orientalist thought would carry into the first days of IAW. This initial hypothesis matches the yielded results since March $1^{\text {st }}$, the first day of IAW, showed the highest usage of the power intervention (6 comments). Therefore, a close critique of the attention and power interventions provides insight into how the online rhetoric changes over the course of IAW.

A rhetorical discourse analysis also reveals a second trend during IAW: the power and attention interventions alternate throughout the week. For example, on March $1^{\text {st }}$, the power intervention was relied upon the most (6 comments). On March $2^{\text {nd }}$, the attention intervention was relied upon the most ( 3 comments). On March $3^{\text {rd }}$, the power intervention was implemented the most again but switched back to the attention intervention on March $4^{\text {th }}$. Therefore, the week follows a power-attention-power-attention-power structure. A possible explanation for this pattern is that after attention is drawn towards a diverting topic, a member must enact the power intervention to steer the conversation back to its origins. Without the presence of the power intervention, the conversation would continue to divert towards irrelevant topics and eventually spiral into an entirely new discussion. Although the use of the power intervention ranked the highest on March $7^{\text {th }}$, the last day of IAW, in a sense, there was still an absence of the power intervention on this day. In the group, the last comment for IAW 2010 is the reference to an Islamic State Apartheid Week petition at York University in Toronto, Canada. There were no concluding remarks or statements of achieved goals and reforms made on behalf of the group 
creators or any of the group members. Since no member took the initiative to wrap the discussion in 2010, the group members may have experienced greater hardship in defining their goals for IAW 2011.

While the attention and power interventions were implemented the most in the UWO group, the third finding suggests that the need intervention was implemented the least of all three rhetorical strategies (total of 21 comments). While power and attention can continue to advance throughout a discussion, once a need is satisfied, group attentiveness shifts to other matters (Brown, Need 14). Therefore, needs are less likely to carry on throughout discussions than the power and attention interventions. Since the group's collective goals made their way into how members identified their individual goals, group membership may impede the construction of individual online identity and construction of individual needs. An analysis of the group comments illustrates that the employment of the power intervention (members who speak up to generate comments such as "what's happening to this group?") is capable of leading to members utilizing the need intervention (the suggestion to revisit the mission statement). Since there are few group members that assume a leadership role and attempt to ground the conversation and revisit the mission statement through their commentary, individuality-stressing needs are employed the least of the needs interventions.

This analysis demonstrates the link between rhetoric and political ideology: rhetoric and its elements of persuasion are the factors that cause individuals to accept an ideology. Although the majority of group members already possessed an anti-IAW perspective before the event week commenced, the rhetoric used in the Facebook group worked to reinforce the initial ideology. There were only several individuals in favour of IAW and comments in the group that reflected dissenting viewpoints. Since political and cultural ideologies were reinforced within the group 
through using the attention, power, and need interventions, this study proves that rhetoric can be a powerful tool to articulate ideology in an online environment. 


\section{CONCLUSION}

This study investigated how online communities can contribute to the formation and development of political dialogue and ideology amongst group members. More specifically, this research used the RSI model, which consists of three rhetorical strategies or interventions, to perform a rhetorical and textual discourse analysis of the comments that users post in the Facebook group UWO Students Against Israel Apartheid Week. There were two primary limitations to this research. First, 87 out of a total of 152 comments were analyzed. Since only a sample set of comments was extracted and examined from the group, this study provides merely a general impression of the rhetorical strategies used.

Second, the RSI model is restricted to three rhetorical strategies: attention, power, and need. Since these three categories are quite broad, they can overlook the emergence of more specific types of rhetorical strategies such as "vocabulary of motives," which is a specific type of language used to encourage members to engage in political activism (Eaton 180). The use of

more defined rhetorical strategies could have led to a more focused discussion of the results.

Despite the limitations of this exploration, a qualitative discourse analysis of the user comments within the UWO group reveals that the attention and power interventions were implemented the most while the need intervention was implemented the least. All three interventions reached their peak at the middle of the event week (March 3-4) then diminished as the week progressed. The rhetoric used alternated between the power and attention interventions, creating a power-attention-power-attention-power structure. Power was the most relied upon intervention at the start and end of the week. Attention was most often directed towards comparisons between Israeli and South African apartheid and an attempt to determine 
the true political and cultural ideologies underlying IAW - anti-Semitism or pro-Palestinianism. In addition to Orientalist thought, appeal to ethos via the stating of credentials and qualifications, a power intervention, was a common strategy that members used when attempting to draw attention to their opinions. An analysis reveals that appeal to ethos is not an effective rhetorical strategy as a stand-alone technique; ethical appeals were most effective when combined with logical and rational appeals. Through an exploration of the power intervention within the group, it became evident that establishing credibility in an online environment can be quite challenging. The need for a clearer mission statement was also expressed. Since the mission statement does not motivate members to pursue action and does not feature outlined objectives and goals, members are less likely to feel purposeful and that they are contributing to their community in a valuable way. Although the mission statement does provide some structure and is intended to have a persuasive purpose, it does not define an online identity with the group. According to Matthew Hartley and Christopher Morphew, mission statements inspire, motivate, and "are certainly important, but not for the direction that they provide. Rather, they serve a legitimating function" (Hartley and Morphew 458). As with all mission statements, online political groups should include mission statements that are created with significant thought and should use rhetoric that provokes a call to action amongst members.

According to Lloyd Bitzer, a rhetorical situation involves three elements: exigence (a problem existing in the world), audience (mediators of change), and constraints (things that limit decisions and actions) (Bitzer 3). The UWO group exemplifies a rhetorical situation because it displays exigence (Israel apartheid discussion), audience (Palestinian and Israeli students), and constraints (group creators threaten to remove commentary that is irrelevant). However, since the constraints presented in this mission statement impede the delivery of certain commentary, the 
Facebook technology enables group creators to confine members to producing certain discourse. In this way, the apartheid discussion becomes one-sided and members are more likely to implement reforms based on a lower diversity of information and opinion. While rhetorical strategies can be effective and used to steer a conversation in a certain direction, users must acknowledge the harmful impact of the constraints when discussing political issues in an online environment.

IAW was welcome on UWO's campus during the 2011 winter academic term. Fortunately, the 2011 commentary within the group reflected less inflammatory language. Taming IAW both on and off university campuses in the future is essential since "the slur of 'Israeli apartheid' as a launch point pervades the campus discourse not only during IAW, but year round. IAW has become a fixture on the academic calendar that needs to be tolerated rather than countered" (Hart 17). Although the attention, power, and need interventions in the UWO group were effective in some respects, overall, they were insufficient to overcome future accusations of Israel's apartheid practices on UWO campus. Although there has been speculation that IAW will be banned from several university campuses within the next several years, for now, it is here to stay.

The results discovered through this analysis suggest that rhetoric is not merely talk. In fact, rhetoric can be quite powerful. However, in order to demonstrate its true power, rhetoric must be implemented more carefully in order to spark new ideas, reforms, and participation. The onus is upon the group creator to use rhetorical strategies and other language constructions to create a mission statement that better resonates with members, reflects their needs, and encourages them to pursue action. Therefore, the group creator must assume the role of the rhetor. This analysis demonstrates the link between rhetoric and political ideology: rhetoric and 
its elements of persuasion are the factors that cause individuals to accept an ideology. However, establishing this connection proves difficult in light of the various ways in which ideology can be defined. Ideology can be viewed as a type of rhetoric, a belief system, or a code of values that places constraints on communication and the behaviour of the social system. As illustrated by Orientalist thought, ideology can be used as a type of rhetoric to influence the mental processes of others. However, the persuasive nature of rhetoric and its strategies can also be used to promote, challenge, or subvert an ideology. Thus, the relationship between rhetoric and ideology is complementary; rhetoric can be used to articulate an ideology and ideology can be used as a form of rhetoric.

Although this research study focuses more on online media's free-for-all ethos rather than the social aspect of social media, it provides a unique opportunity to discuss the role of political communication in an online, technological era. Since Facebook has a special significance for the millennial generation, it is an effective outlet to facilitate political dialogue among youth, offering notable political viewpoints and information that they may otherwise overlook. Adults younger than age thirty lead the way for gathering political information from the Internet (specifically social networking sites), which "represents a significant generational difference in where older and younger people turn for information" (Kushin 27). The results of this textual discourse analysis support the conclusions drawn from previous studies of online political communication: through the postings of friends and acquaintances, online political groups bring politics into the daily lives of young adults and affect their political interest in certain situations, making politics more familiar, personal, and accessible (Kushin and Yamamoto 614). Since members of the UWO group relied primarily on user-generated textual commentary, they may have encountered new perspectives and opinions that were not as well-expressed via traditional 
news media, encouraging further information-seeking processes to increase political awareness. Thus, the UWO group illustrates the great potential of online communities to convey a rhetorical situation.

Since the Internet operates as a "self-sustaining reference system," the judgments drawn from online content are often circular (Warnick 48). Websites are often linked to a plethora of other web pages that provide new, different contexts and information. Thus, the distributed network of the Internet signifies distributed credibility. To determine reputable sources, users must harness their collective intelligence and exercise good judgment when evaluating online content. Yet the relative newness of social media websites may indicate that users may not be utilizing the online political groups that these sites offer to the best of their advantage. As illustrated by the UWO Facebook group, online discussions can morph into a platform for hateful discussion that diverts from a critical debate of the political issues at stake. However, as UWO students gain more experience and understanding of the implications behind online political communication, they will likely begin to utilize the Facebook medium to produce more politically-focused dialogue within their group discussions. Although numerous studies have proven the political utility of online media, researchers should continue to explore its role in fostering online political communication and engagement. 


\section{WORKS CITED}

Althusser, Louis. Lenin and Philosophy and Other Essays. New York: Monthly Review Press, 1971.

Amdur, Reuel. "Calling for Moral Investment at Carleton." The Canadian Charger. 23 Mar. 2011. 11 Jul. $2011<$ http://www.thecanadiancharger.com/page.php?id=5\&a=833>.

Ancu, Monica, and Raluca Cozma. "MySpace Politics: Uses and Gratifications of Befriending Candidates." Journal of Broadcasting \& Electronic Media 53 (2009): 567-583.

Balsam, Corey. "Judith Butler to Speak at Israeli Apartheid Week in Toronto." Rabble.ca. 4 Mar. 2011. 16 Jun. $2011<$ http://rabble.ca/news/2011/03/judith-butler-speak-israeli-apartheidweek-toronto>.

Bar-Tal, Daniel. "Israeli-Palestinian Conflict: A Cognitive Analysis." International Journal of Intercultural Relations 14 (1990): 7-29.

Baumgartner, Jody, and Jonathan Morris. "MyFaceTube Politics: Social Networking Websites and Political Engagement of Young Adults. Social Science Computer Review 18.1 (2010): 24-44.

Bitzer, Lloyd. “The Rhetorical Situation.” Philosophy \& Rhetoric 1 (1968): 3.

Boldt, Perry. "Middle East Tensions Hit Home." Capital News Online: A Publication of Carleton University's School of Journalism \& Communication. 2000. 19 Jun. 2011 $<$ http://www.carleton.ca/JMC/cnews/20102000/n1p.htm>.

Brown, William. "Attention and the Rhetoric of Social Intervention." Quarterly Journal of Speech 68 (1982): 17-27.

---. "Ideology as Communication Process." Quarterly Journal of Speech 64.2 (1978): 123-140.

---. "Need and the Rhetoric of Social Intervention." Ohio State University (1987): 1-44.

--- "Power and the Rhetoric of Social Intervention." Communication Monographs, 53.2 (1986): 180-199.

Burke, Kenneth. A Rhetoric of Motives. Berkeley: University of California Press, 1969.

Canadian Breast Cancer Foundation. “About Us.” Run for the Cure. 2011. 15 Jun. 2011 $<$ http://www.runforthecure.com/site/PageServer?pagename=2011_About_Us $>$.

Crenshaw, Carrie, and David Roskos-Ewoldsen. "Rhetoric, Racist Ideology, and Intellectual Leadership." Rhetoric \& Public Affairs 2.2 (1999): 275-302.

Donnelly-Smith, Laura. "Political Engagement in the Age of Facebook: Student Voices." Peer Review 10.2 (2008): 37-39. 
Eaton, Marc. "Manufacturing Community in an Online Activist Organization: The Rhetoric of MoveOn.org's Emails." Information, Communication \& Society 13.2 (2010): 174-192.

Fernandes, Juliana, et al. "The Writing on the Wall: A Content Analysis of College Students' Facebook Groups for the 2008 Presidential Election.” Mass Communication and Society 13.5 (2010): 653-675.

Finlayson, Alan. "From Beliefs to Arguments: Interpretive Methodology and Rhetorical Political Analysis.” British Journal of Politics and International Relations 9.4 (2007): 545-563.

Flanagin, Andrew, Ryan Medders, and Miriam Metzger. "Social and Heuristic Approaches to Credibility Evaluation Online.” International Communication Association (2009): 1-40.

Freeden, Michael. Ideology: A Very Short Introduction. New York: Oxford University Press, 2003.

Gareis, Elisabeth. "Habermas to the Rescue." Business Communication Quarterly 73.2 (2010): 166-175.

Gonzalez, Alberto. "'Participation' at WMEX-FM: Interventional Rhetoric of Ohio Mexican Americans.” Western Journal of Speech Communication 53 (1989): 398-410.

Gring, Mark. "Attention, Power, and Need: The Rhetoric of Religion and Revolution in Nicaragua." World Communication 27.4 (1998): 27-37.

Gring, Mark, and Susan Opt. The Rhetoric of Social Intervention: An Introduction. Thousand Oaks: SAGE Publications Inc., 2009.

Gulati, Girish, and Christine Williams. "Social Networks in Political Campaigns: Facebook and Congressional Elections 2006, 2008." American Political Science Association (2009): 225.

Habermas, Jürgen. "Moral Consciousness and Communicative Action.” Massachusetts: MIT Press, 1999.

Haggarty, Jaclyn. "Anti-Semitic Graffiti Found Twice This Week in Weldon.” The Gazette. 3 Apr. 2008. 11 Jul. 2011 $<$ http://www.gazette.uwo.ca/article.cfm?section=FrontPage\&articleID=1243>.

Hakansson, Nicklas. "Election Rhetoric of Political Parties: An Appraisal and a Proposal." The Public 4.3 (1997): 81-95.

Hart, Lawrence. "IAW: A Legacy of Inaction.” Canadian Jewish News. 3 Mar. 2011, 17.

Hartley, Matthew, and Christopher Morphew. "Mission Statements: A Thematic Analysis of Rhetoric Across Institutional Type.” Journal of Higher Education 77.3 (2006): 456-471.

IAW. "Israel Apartheid Week." Israel Apartheid Week. 16 Jun $2011<$ http://apartheidweek.org>.

In der Smitten, Susanne. "Political Potential and Capabilities of Online Communities." German Policy Studies 4.4 (2008): 33-62. 
Kahn, Seth, and Jonghwa Lee. Activism and Rhetoric: Theories and Contexts for Political Engagement. New York: Routledge, 2011.

Kohut, Andrew. "Social Networking and Online Videos Take Off: Internet's Broader Role in Campaign 2008." The Pew Research Center for the People and the Press. 8 Jan. 2011. 13 Jul. $2011<$ http://www.pewinternet.org/pdfs/Pew_MediaSources_jan08.pdf>.

Kushin, Matthew. "How Young Adults and Social Media are Challenging Traditional Perspectives of Civic Life." Rocky Mountain Communication Review 6.1 (2009): 26-31.

Kushin, Matthew, and Masahiro Yamamoto. "Did Social Media Really Matter? College Students' Use of Online Media and Political Decision Making in the 2008 Election." Mass Communication \& Society 13.5 (2010): 608-630.

Lariscy, Ruthann, and Kaye Sweetser. "Candidates Make Good Friends: An Analysis of Candidates' Uses of Facebook." International Journal of Strategic Communication 2 (2008): 175-198.

Lippmann, Walter. Public Opinion. Piscataway: Transaction Publishers, 1922.

Lurie, Rob. "Montreal Jewish School's Library Reopens." CTV.ca. 7 Dec. 2004. 11 Jul. 2011 $<$ http://www.ctv.ca/servlet/ArticleNews/story/CTVNews/20041207/school_library_0412 07?s_name $=$ I\&no_ads $=>$.

My Canada. "CBC Poll: Great Canadian Wish List Results.” 4mycanada. 2007. 15 Jun. 2011 $<\mathrm{http}: / /$ www.4mycanada.ca/News/GreatCanadianWishList.html $>$.

NORC. "A Guide to Community Action: Mission Statements." NORC. 26 Jun. 2011 $<\mathrm{http}$ //www.norcblueprint.org/toolbox/mission_statement_guidelines $>$.

North American Jewish Data Bank. Mandell L. Berman Institute. 25 May 2011 $<$ http://www.jewishdatabank.org>.

Obiedat, Nawaf. "The Pragma-Ideological Implications of Using Reported Speech: The Case of Reporting on the Al-Aqsa Intifada." International Pragmatics Association 16.2 (2006): 275-304.

Park, Namsu, et al. "Being Immersed in Social Networking Environment: Facebook Groups, Uses and Gratifications, and Social Outcomes." Cyberpsychology and Behaviour 12.6 (2009): 729-733.

Poliakov, Rita. "UWO Students Receive Threatening Messages." Canadian Jewish News. 11 Mar. 2010: 28.

Rheingold, Howard. Smart Mobs: The Next Social Revolution. Perseus Books Group: Cambridge, 2003. 
Rumleski, Kathy. "Canada Most Pro-Israel in World: Author." London Free Press. 3 Mar. 2010. 12 Jul. $2011<$ http://www.lfpress.com/entertainment/books/2010/03/02/13090106.html>.

Said, Edward. Orientalism. New York: Vintage Books, 1979.

Stone, Cheryl. "Facebook Threats Made Against Students." The Gazette. 3 Mar. 2010. 9 Jun. $2011<$ http://www.westerngazette.ca/2010/03/03/facebook-threats-made-against-uscclubs-2/>.

Tessler, Mark. A History of the Israeli-Palestinian Conflict. Bloomington: Indiana University Press, 1994.

UJA Federation: Public Affairs. "IAW on Toronto Campuses.” 3 Mar. 2011.

Warnick, Barbara. Rhetoric Online: Persuasion and Politics on the World Wide Web. Peter Lang Publishing, 2007. 